Arndt-Corden Department of Economics Crawford School of Public Policy

ANU College of Asia and the Pacific

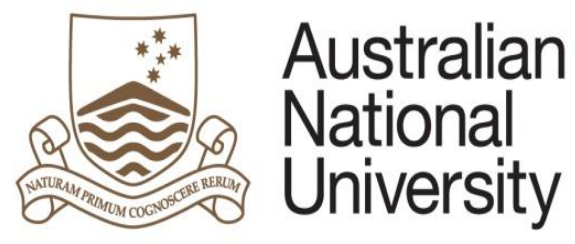

\title{
COVID-19 and global beverage markets: Implications for wine
}

\author{
Glyn Wittwer \\ Centre of Policy Studies, \\ Victoria University \\ and \\ Kym Anderson \\ University of Adelaide and \\ Australian National University
}

April 2021

Working Papers in Trade and Development

No. $2021 / 12$ 
This Working Paper series provides a vehicle for preliminary circulation of research results in the fields of economic development and international trade. The series is intended to stimulate discussion and critical comment. Staff and visitors in any part of the Australian National University are encouraged to contribute. To facilitate prompt distribution, papers are screened, but not formally refereed.

Copies are available at https://acde.crawford.anu.edu.au/acde-research/working-papers-tradeand-development 


\title{
COVID-19 and Global Beverage Markets: Implications for Wine
}

\author{
Glyn Wittwer ${ }^{\mathrm{a}}$ and Kym Anderson ${ }^{\mathrm{b}}$
}

\begin{abstract}
This paper provides an empirical case study of impacts of the COVID-19 pandemic on global beverage markets, particularly the wine sector. Both international trade and domestic sales have been adversely affected by temporary shifts away from on-premise sales by social distancing measures and self-isolation that led to closure of restaurants, bars and clubs plus declines in international travel and tourism. Partly offsetting this has been a boost to off-premise and direct e-commerce sales. We first estimate those impacts in 2020 and their expected partial recovery in 2021 using a new model of global beverage markets. A further recent disruption to global wine trade has been the imposition by China in late 2020 of prohibitive tariffs on its imports of bottled wine from Australia. Its diversionary and trade-reducing effects are compared with those due to COVID-19.
\end{abstract}

JEL Codes: C63, D12, F14, F17, Q17

Keywords: Beverage market modeling, pandemic responses by consumers, prohibitive tariffs, trade diversion

This paper replaces an early analysis reported in AAWE Working Paper 249, May 2020, at https://www.wine-economics.org/wp-content/uploads/2020/05/AAWE WP249.pdf

The authors are grateful for financial support from Wine Australia and from the University Adelaide's Faculty of the Professions and School of Agriculture, Food and Wine, under Research Project UA1803-3-1. Forthcoming in the Journal of Wine Economics.

${ }^{a}$ Centre of Policy Studies, Victoria University, 300 Flinders Street, Melbourne, Vic. 8001 Australia; Email: glyn.wittwer@vu.edu.au

${ }^{\mathrm{b}}$ Wine Economics Research Centre, School of Economics, University of Adelaide, Adelaide SA 5005, Australia and Arndt-Cordon Department of Economics, Australian National University, Canberra ACT 2600; Email: kym.anderson@adelaide.edu.au (corresponding author) 


\section{COVID-19 and Global Beverage Markets: Implications for Wine}

\section{Introduction}

Policy responses to the coronavirus COVID-19 pandemic in 2020 have caused a global economic recession, the severity of which has not been seen since the 1930s. How is that affecting the world's beverage markets and, in particular, what does it mean for the wine industry in the short-to medium term?

Of course no-one can answer this question with any precision, because it depends on many factors that remain very uncertain. Early on, the European Commission (2020) warned that the volume of wine consumption in the European Union (EU) would be $8 \%$ lower in 2020 than the previous five years' average, bearing in mind that the $70 \%$ of sales that are offpremise are expected to be a little above average this year as many people self-isolate at home and avoid restaurants, bars and pubs. Social distancing made large celebrations and partying impossible in lockdown periods and so was especially damaging to sparkling wine sales. Maxime Toubart, Chairman of the Champagne producers' organisation SGV, noted on 5 May 2020 that Champagne sales in March and April 2020 were down 80\% compared with a year earlier.

How have sales declines during 2020 compared with wine production in the EU and other parts of the world? How different will those impacts for wine be from those affecting beer and spirits? With the help of a new model of global beverage markets (Wittwer and Anderson 2020a), this article specifies hypothetical shocks and estimates their effects on various nations' beverage production, consumption, trade and prices. The latest global macroeconomic projections from the IMF (2020) are drawn on to simulate the market impacts of (i) downturns in incomes in 2020 and a switch from on-premise to off-premise consumption on various beverage demands and the response of suppliers and (ii) a gradual recovery beginning in 2021 that is expected to be phased over several more years. A further recent disruption to global wine trade has been the imposition by China in late 2020 of prohibitive tariffs on its imports of bottled wine from Australia (its largest source of imports). The diversionary and net-trade-reducing effects of that are estimated using the same global beverage market model, and are compared with those due to COVID-19.

In what follows we explain the nature of the exercise, present global and key national results, highlight caveats, and stress that these are not forecasts but simply projections based on explicit assumptions about an uncertain environment. 


\section{Basic Economics of COVID-19's Global Market Shock}

Every sector of most national economies has been affected by COVID-19. Production has been curtailed and product demand has fallen to varying extents across sectors thanks to social distancing and self-isolation measures or choices. In the case of beverages, sales to consumers are affected not only by declines in incomes but also by governmental measures that have led to closures of restaurants, bars and clubs plus a huge decline in international travel and tourism and hence also in duty-free sales, consumption on airlines and cruise ships, and visits to cellar doors.

Certainly there has been some offsetting off-premise sales and, for smaller producers, more direct e-commerce sales; and there were some increases in consumer stocks in anticipation of one or more periods of self-isolation at home. Off-premise beverage sales typically tend to be lower priced than on-premise purchases though. During the global financial crisis of 2008-09, the decline in both quantity and quality of sparkling wine sales was especially marked - and the subsequent rate of growth from the lower 2009 base was slower than it had been in preceding years, notwithstanding the Prosecco boom of the past decade (OIV 2020).

Wine production has been affected relatively little by COVID-19, even in the Southern Hemisphere where the 2020 vintage timing coincided with when the coronavirus struck. This was because exemptions were made, including to labor movements, to allow the industry to complete its crush. Unlike wine, production of beer and spirits is not dependent on a perishable crop, and its production processes have not been seriously affected by social distancing measures. Hence supply adjustments to changed market signals can be expected to be as per usual when demand patterns change, albeit with some disposal of barreled beer after the first few weeks of on-premise closures. Small craft breweries and distilleries, like small wineries, have sought to expand their e-commerce channels, to varying degrees that have only partly substituted for lost traditional sales.

\section{Modelling Beverage Markets}

Analysis of markets for the three main alcoholic beverage groups (wine, beer and spirits) requires a global economic model of national markets connected through international trade, in which the interactions between each nation's producers and consumers of these three 
beverages are explicitly recognized. Wittwer and Anderson (2020a) provide such a model. It is calibrated to 2016-18 data, but for present purposes it is updated to 2019 and then projected to 2020 and beyond calendar years.

In an early version of this analysis (Wittwer and Anderson 2020b), following IMF macroeconomic growth rate projections of April 2020 which took into account expected COVID-19 impacts on GDP, a V-shaped recover in 2021was assumed. In the present paper, a much slower ('Nike tick') recovery is assumed that stretches beyond 2021, based on the latest (October) projections by the IMF (2020). Results are reported each year relative to a noCOVID business-as-usual baseline simulation that reflects a medium-term global slowdown that was expected in the absence of COVID-19 (so as to avoid exaggerating the impact of the pandemic).

The assumed extent of the macroeconomic shock to aggregate household expenditure in 2020 and its subsequent partial recovery in 2021 are shown in the Appendix Table A1 for 51 countries or residual country groups. The average assumed differences between the COVID and no-COVID scenarios in aggregate household expenditure globally are $-7.5 \%$ in 2020 and $-5.5 \%$ in 2021 . The only other modelling change made in this global scenario is that wine demand is assumed to move away from high-quality sparkling wines (fewer celebratory events) and slightly toward high-quality still wine in 2020: as a consequence of the closure of restaurants, pubs and clubs for several months, consumers were able to afford better wines to drink at home without on-premise mark-ups. Specifically, we assume there is a temporary $30 \%$ taste swing away from sparkling wine and a 5\% swing in favor of super-premium still wine during 2020.

There is of course a huge amount of uncertainty around the 'best guesses' by the IMF. In a lengthy global macro modelling article, McKibbin and Fernando (2020) examine seven COVID scenarios in which the aggregate household expenditure shock for Australia in 2020 ranges from $0 \%$ to $-9 \%$, for example. The IMF projections appear to be close to national forecasts of major economies at that time for 2020. What is more uncertain is how rapidly economies will recover post-2020. The latest IMF projections for 2021 imply not a perfect V pathway but rather in the shape of a Nike tick (less than full recovery in 2021 due to, for example, older stood-down workers not being re-employable). An even more-gradual return to 2019 expenditure levels than assumed here, stretching over several subsequent years, is 
also possible. ${ }^{1}$ This could be due to consumers being slow to return to crowded places even after restrictions are lifted, for example. Also of concern is the rate at which vaccinations are distributed globally. As Bown, de Bolle and Obstfeld (2021) starkly put it, the pandemic is 'not under control anywhere unless it is controlled everywhere'.

In the GLOBAL-BEV model, wine markets have been disaggregated into four types, namely non-premium (including bulk), commercial-premium, and super-premium still wines, plus sparkling wine. Commercial-premium still wines are defined to be those between US\$2.50 and \$7.50 per litre pre-tax at a country's border or wholesale. Beer and spirits are not split into regular and craft categories, because the latter still have small market shares in volume terms and are very minor players in international trade (and global trade data are not disaggregated by quality). The world is divided into 44 individual nations with all other countries being captured in seven composite residual regions (listed in Appendix Table 1). The primary sources of data for constructing the GLOBAL-BEV model's baseline database for 2016-18 are Anderson and Pinilla (2020) plus Anderson (2020) for taxes on beverage consumption and imports, Holmes and Anderson (2017) for wine, beer and spirits average consumer expenditure data, and United Nations (2019) for volume and value of international trade in beverages.

This GLOBAL-BEV model has income- and price-responsive demand equations, price-responsive supply equations and hence quantities and prices for each of the grape and wine products and for beer and spirits, plus for a single composite of all other products in each country such that it has elements of an economywide model. Grapes are assumed to be not traded internationally, but other products are both exported and imported. All prices are expressed in real (2017) US dollar terms. However, to avoid complicating the scenarios, it is assumed that currency exchange rates and overall consumer price indexes for each country do

\footnotetext{
${ }^{1}$ The removal of government-imposed restrictions may not be enough for consumers to return to previous economic and social activities. Maloney and Taskin (2020) find for the U.S. that much of the decrease in mobility is voluntary and driven by the number of COVID19 cases (greater awareness of risk). They find mandated closing of nonessential businesses, sheltering in place and school closures are effective, but their total contribution is dwarfed by voluntary responses. This suggests that much social distancing may continue even after restrictions are lifted. Their results are consistent across countries and income groups except for the poorest in low-income countries who could not afford to abandon their sources of livelihood. That is, removing restrictions may not yield a fast recovery if consumers are unconvinced that the COVID risk has fallen. That perceived risk depends heavily on the pace and success of the rollout of vaccines national and globally.
} 
not change over the two years examined, so value changes also can be interpreted as being nominal and in local currencies.

\section{A. Producer Price and Consumption Effects}

Real incomes and hence aggregate spending are expected by the IMF (2020) to be lower in most countries in 2020 relative to what they would have been without COVID, but to varying extents (Appendix Table 1). The expected drops in aggregate national expenditure in 2020 are projected to lower real producer prices of beverages in all regions, but somewhat more for wine than for beer and spirits, due to the taste swing against sparkling wine (Table 1(a)). The falls in average prices vary across countries much more for wine than for other beverages. This is partly because of the cross-country difference in price drops for each of the four different types of wines. Prices for spirits drop less than for wine and beer because China and India dominate the global volume of spirits consumption (a combined share of almost 60\%) and their incomes are expected to continue to grow in 2020, albeit far less rapidly than in the recent past.

[Insert Table 1 about here]

The assumed part-reversal of incomes in 2021 (Table 1(b)) is insufficient to make much impact in narrowing the difference between prices in the COVID and business-as-usual scenarios. This reflects the re-imposition of lockdowns and the spate of second-wave coronavirus infections in numerous countries, postponing the recovery that had initially been hoped for in late 2020 .

The projected changes in volumes of beverages consumed are reported in Table 2 . The world is projected to involve $7 \%$ less overall consumption of wine and a somewhat smaller shortfall in beer and spirits consumption in 2020 (4\%-5\%). Within the wine group, sales of super-premium still wine consumption drop less than lower-priced wine (due to a taste swing towards consuming higher-price wines off-premise as expenditure on-premise falls markedly). But sparkling wine is projected to be down by more than a quarter compared with business-as-usual in 2020, a reflection of the widespread cancellation of large celebratory activities in 2020. Beverage consumption is affected in Asia almost as much as elsewhere, despite its income growth being curtailed less than in other regions, because Asia's income difference between the COVID and no-COVID scenarios is still large in percentage point terms.

[Insert Table 2 about here] 
Sales growth is projected to occur in 2021, but the volume of consumption is still expected to be lower than it would have been without COVID. It would have been lower still had average prices not remained subdued.

The values of consumption alter considerably more than their volumes, because prices also fall and then begin to rise over the two years; and they alter more for fine (especially sparkling) wines than for commercial and non-premium still wines. For the world as a whole, the volume of all wine consumption is $7 \%$ lower in 2020 than it would have been without COVID, and 4\% lower in 2021, whereas real expenditure on wine is $13 \%$ lower in 2020 and still $8 \%$ lower in 2021. For sparkling wine globally, the differences are even starker. Beer and spirits expenditures globally are projected to fall less than for wine (Table 3).

[Insert Table 3 about here]

\section{B. Effects on International Trade}

The volumes of world trade in the various wine categories alter by percentages slightly smaller in size to those for the volume of global consumption, but their values alter by somewhat larger percentages than changes in consumer expenditure because of the changes also in unit values of traded wines. In particular, the percentage fall in wine export value is three times the fall in their volume in both 2020 and 2021 (Tables 4 and 5). Australia and New Zealand are affected a little less adversely than other exporters of wine, but still harmed. Their exports are hurt less because sparkling wine is a smaller share of their exports than of the rest of the world's and that is the wine type hit hardest by the COVID lockdowns.

[Insert Tables 4 and 5 about here]

World imports change to the same extent as world exports of course. Table 6 shows that wine imports in 2020 are projected to be lower in Western Europe and North America by more than twice as much in percentage value as in percentage volume terms. In Asia, the value to volume difference is even greater, because a relatively high share of Asia's imports are fine wines, and their prices have altered more than those of commercial wines.

[Insert Table 6 about here]

\section{What About China's New Tariff on Bottled Wine Imports from Australia?}

In late 2020 China imposed very high 'temporary' tariffs on its imports of bottled wine from its largest supplier (Australia), pending its investigation into alleged producer subsidies to and dumping by Australian wineries. The tariffs vary by firm, ranging from $113 \%$ to $218 \%$ and averaging more than $170 \%$; and they are expected to remain at a high level once those 
official investigations are completed in August 2021 - possibly for several years. Their imposition, which is a response to a number of Australian government initiatives the China Communist Party disliked, contravenes the free trade agreement between the two countries. The Australian Government may take the matter to the WTO - but several years would elapse before the case is resolved there. That reality is forcing Australian producers to look to alternative markets, and simultaneously is encouraging other wine-exporting countries to sell more to China.

The net effect of a near-prohibitive ban on imports from one country is less than the gross effect, because shipments can be directed to alternative markets that will become more accessible as other exporters divert some of their trade to China. But this is harder for products that are more differentiated by country of origin. It is also harder when the market in the destination involved (China) is different from those of other destinations - as it is for Australian wine: the average export price of Australian wine destined for China in recent years has been three times the average sold in non-Asian markets, and most are red wines rather than being half white wines as in Australia's other markets. ${ }^{2}$ Nor will it be easy to displace imports in Australia's domestic wine market since imports account for only 15 percent of domestic sales and a sizeable majority of those imports are white wines (most from New Zealand).

Wittwer and Anderson (2021) have used their GLOBAL-BEV model to estimate the global trade consequences of this major blow to Australian wine exports. They did so by imposing a 170\% tariff on China's imports of Australian bottled wine on the model's business-as-usual baseline (that is, ignoring COVID). That tariff virtually wipes out Australia's wine exports to China. It hits fine wine exports especially, since $52 \%$ of the value of sales to China recently have been above AUD15 per litre (compared with just 5\% of Australia's sales to the US and 3\% to the UK). That loss in exports to China amounts to US\$785 million per year. The total loss of exports is much smaller than that, at US\$225 million, as some shipments from Australia are diverted to other countries. According to the

\footnotetext{
${ }^{2}$ China in 2020-21 has been restricting imports of several other products from Australia, including barley and coal. The prospects for finding (almost) equally attractive alternative markets for those two products are much higher than for wine, however, since they are far more homogeneous: in each case, the average price of Australian exports to China is very close to the average price of Australian exports to the rest of the world. Studies using global CGE models to analyse China's sanctions on those two products have shown the effects on prices and total trade to be relatively modest (Cao and Greenville 2020; Giesecke, Tran and Waschik 2021).
} 
GLOBAL-BEV Model, Australia will raise its annual exports to the US by US\$120 million, to Canada by $\$ 49 \mathrm{~m}$, to the UK by $\$ 45 \mathrm{~m}$, to other Asia by $\$ 42 \mathrm{~m}$, etc. Recall, though, that this is compared with business as usual: Australian wine exports grew by $30 \%$ in the four years to 2019 in US\$ terms, so this just erodes some of that recent growth.

This shock is estimated to reduce the average producer price of wine in Australia by $11 \%$, of winegrape prices by $12 \%$, of the volume of its exports by $13 \%$, and of its total wine sales value by $14 \%$ (a drop of $22 \%$ for exports and $2 \%$ for the now-lower-priced albeit $3 \%$ larger volume of domestic sales). These price drops and export losses are greater than the estimates reported above for COVID's impact on Australia, while its losses in domestic sales are smaller than those due to COVID.

Figure 1 reveals how the origins of China's wine imports may change as a consequence of its new tariff. France, Chile, Spain, Italy and the United States are projected to be the main beneficiaries (in that order). But their increase in imports only partly offset the fall in imports from Australia, with China's total wine imports being lower by US $\$ 215 \mathrm{~m}$ per year because of this new protectionist barrier.

[insert Figure 1 about here]

\section{Caveats}

As mentioned at the outset, results depend heavily on our assumptions about the extent to which economies go into recession in 2020 and the extent and speed of recovery in the years to follow. The V-shaped projection in April 2020 by the IMF, implying a near-return to 2019 incomes by 2021, was more optimistic than many commentators suggested at the time, and also than the IMF's October 2020 projections. Even our assumed Nike tick-type recovery may be too optimistic, as the trajectory may be more U-shaped, delaying the return to growth by one or more years. The International Wine and Spirits Research group, for example, projects it will take five years for global alcohol consumption to return to 2019 levels after the COVID-inspired slump of 2020, and possibly even longer in the UK and US.

Also assumed above is that beverage-specific national policies affecting production, consumption and trade are unchanged (apart from the China tariff simulation). Yet several are already in train or being contemplated. Excise taxes on alcohol may rise to help reduce fiscal deficits. US tariffs on imports of EU wineas and spirits (in retaliation for subsidies to Airbus) may be prolonged, or removed, by the new Biden Administration. And numerous bilateral preferential trade agreements following Brexit are expected to be negotiated from 2021 by 
both the UK and the EU27, which also aare likely to have non-trivial effects on the world's wine trade (Anderson and Wittwer 2018).

\section{Concluding Remarks}

The above results suggest wine sales globally are being hurt by COVID-19, and markets may take years rather than months to recover. The damage is greatest for premium sparkling wines, but all wine quality segments are affected. The impacts are not equal across countries though: wine-exporting countries would lose from selling less at lower prices, while wineimporting countries would benefit from lower wine import prices. Within each country, consumers would be paying less for wine at the expense of grapegrowers and wineries. Meanwhile, on-premise sales will be lost to off-premise sellers, hurting small premium producers and independent retailers more than large-scale producers of lower-quality wines sold in supermarkets. Hopefully the financial system and the current low interest rates will be able to carry firms through the recovery period.

\section{References}

Anderson, K. (2020). Consumer Taxes on Alcohol: An International Comparison over Time. Journal of Wine Economics, 15(1), 42-70.

Anderson, K., and Pinilla, V. (2020). Annual Database of Global Wine Markets, 1835 to

2018. Wine Economics Research Centre, University of Adelaide. Updated January 2021, at www.adelaide.edu.au/wine-econ/databases

Anderson, K., and Wittwer, G. (2018). Cumulative Effects of Brexit and Other UK and EU27 Bilateral FTAs on the World's Wine Markets. The World Economy, 41(11), 2883-2894.

Bown, C.P., de Bolle, M., and Obstfeld, M. (2021). The Pandemic is Not Under Control Anywhere Unless it is Controlled Everywhere. Blog at Peterson Institute for International Economics, Washington DC, 2 February. https://www.piie.com/blogs/realtime-economicissues-watch/pandemic-not-under-control-anywhere-unless-it-controlled Cao, L., and Greenville, J. (2020). Understanding How China's Tariff on Australian Barley Exports Will Affect the Agricultural Sector. ABARES Research Report 20.14, Canberra: Australian Bureau of Agricultural and Resource Economics and Sciences, June. 
European Commission (2020). Short-term Outlook for EU Agricultural Products in 2020. Brussels: European Commission, Spring. https://ec.europa.eu/info/sites/info/files/foodfarming-fisheries/farming/documents/short-term-outlook-spring-2020_en.pdf

Giesecke, J.A., Tran, N.H., and Waschik, R. (2021). Should Australia be Concerned by Beijing's Trade Threats: Modelling the Economic Costs of a Restriction on Imports of Australian Coal. Australian Journal of Agricultural and Resource Economics, 65 (forthcoming).

Holmes, A.J., and Anderson, K. (2017). Annual Database of National Beverage Consumption Volumes and Expenditures, 1950 to 2015. Accessible at www.adelaide.edu.au/wineecon/databases/alcohol-consumption, July.

IMF (2020). World Economic Outlook. Washington DC: International Monetary Fund, October.

McKibbin, W., and Fernando, R. (2020). Global Macroeconomic Scenarios of the COVID-19 Pandemic. COVID Economics,, 39, 1-58, 23 July.

Maloney, W., and Taskin, T. (2020),. Determinants of Social Distancing and Economic Activity During Covid-19: A Global View. Covid Economics, 13, 157-177, 4 May.

OIV (2020). State of the Vitiviniculture World. Paris: Organisation Internationale de la Vigne et du Vin (International Organization of Vine and Wine), April. http://oiv.int/en/oiv$\underline{\text { life/current-situation-of-the-vitivinicultural-sector-at-a-global-level }}$

United Nations (2019). COMTRADE Database. Accessed 15 August 2019 at https://comtrade.un.org/db

Wittwer, G., and Anderson, K. (2020a). A Model of Global Beverage Markets. Journal of Wine Economics, 15(3), 330-354.

Wittwer, G., and Anderson, K. (2020b). COVID-19 and Global Beverage Markets: Implications for Wine. AAWE Working Paper 249, May 2020, at https://www.wineeconomics.org/wp-content/uploads/2020/05/AAWE_WP249.pdf

Wittwer, G., and Anderson, K. (2021). How Will Markets Adjust to China's New Tariff on Imports of Australian Wine? Wine and Viticulture Journal, 36(2), 66-70, Autumn. 
Figure 1: Change in value of China's wine imports by source, pre- and post-tariff imposition of a $170 \%$ tariff on bottled wine imports by China from Australia (US\$ million per year)

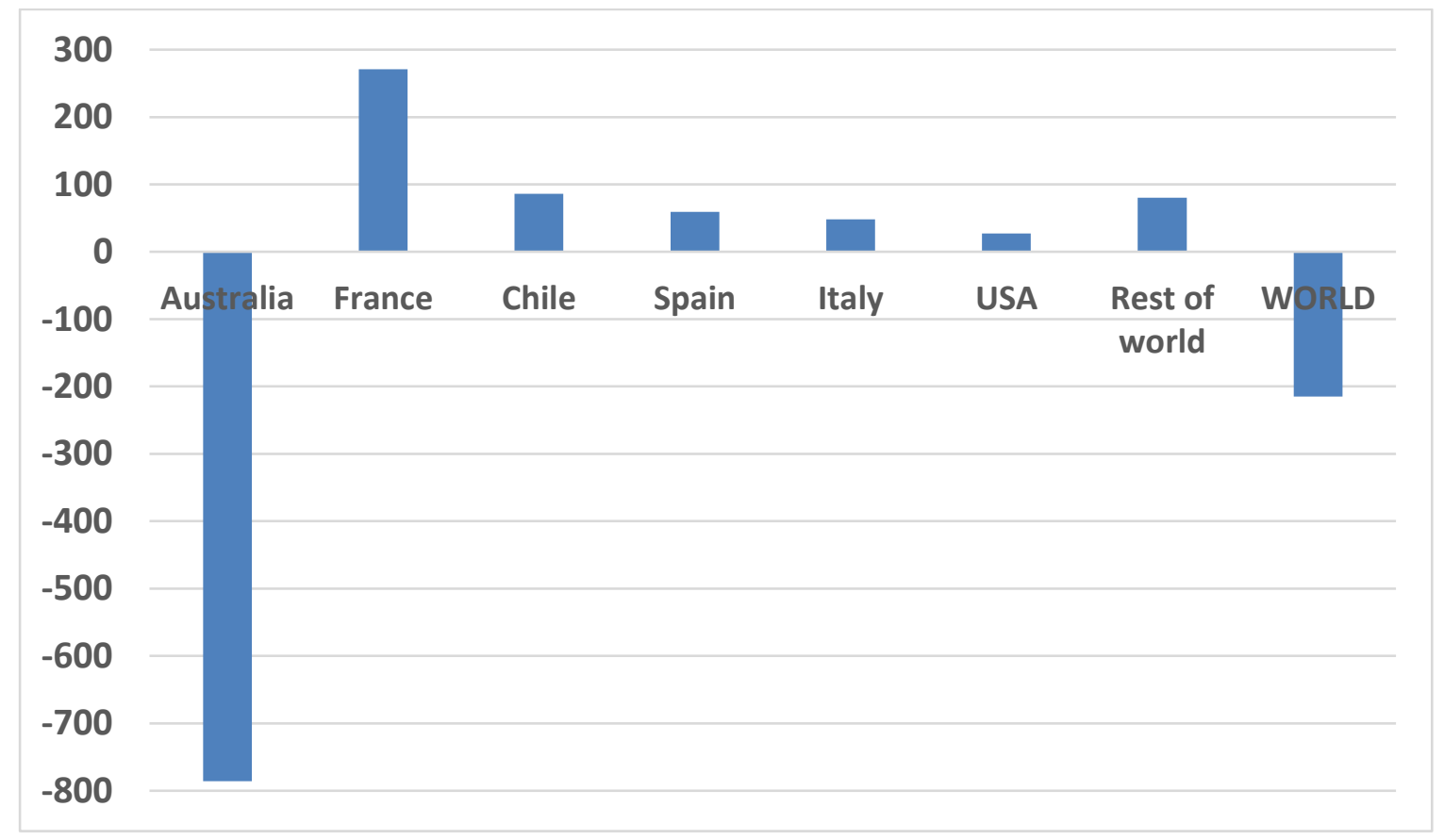

Source: Authors' GLOBAL-BEV model results. 
Table 1: Real ${ }^{\mathrm{a}}$ beverage producer prices, 2020 and 2021 (\%, relative to no-COVID baseline)

(a) 2020

All wine

NPWine

CPWine

SPWine

Sparkling

Beer

Spirits

$\begin{array}{rrrrrrr}\text { WEur } & \text { US\&Can } & \text { LatAmer } & \text { SthAfr } & \text { Aust } & \text { NZL } & \text { ROW } \\ \mathbf{- 1 1} & \mathbf{- 9} & \mathbf{- 9} & \mathbf{- 1 0} & \mathbf{- 7} & \mathbf{- 5} & \mathbf{- 1 3} \\ -6 & -5 & -3 & -5 & -5 & -4 & -6 \\ -9 & -9 & -8 & -9 & -8 & -8 & -9 \\ -5 & -6 & -6 & -5 & -4 & -5 & -5 \\ -26 & -27 & -25 & -27 & -26 & -26 & -29 \\ -7 & -6 & -7 & -7 & -5 & -6 & -5 \\ -5 & -6 & -6 & -6 & -6 & -6 & -9\end{array}$

(b) 2021

All wine

NPWine

CPWine

SPWine

Sparkling

Beer

$\begin{array}{rr}\text { WEur } & \text { US\&Can } \\ -7 & -8 \\ -4 & -5 \\ -7 & -7 \\ -8 & -9 \\ -7 & -9 \\ -5 & -6 \\ -4 & -6\end{array}$

LatAme
-7
-3
-6
-9
-9
-6
-5

$\begin{array}{rrrr}\text { SthAfr } & \text { Aust } & \text { NZL } & \text { ROW } \\ -\mathbf{7} & \mathbf{- 6} & \mathbf{- 7} & \mathbf{- 8} \\ -4 & -4 & -4 & -5 \\ -7 & -6 & -6 & -8 \\ -8 & -8 & -7 & -8 \\ -11 & -8 & -8 & -10 \\ -7 & -6 & -5 & -5 \\ -6 & -6 & -6 & -8\end{array}$

Note: In this and subsequent tables, NP is non-premium, CP is commercial premium and SP is super premium still wine.

${ }^{a}$ Expressed in US dollars but in these simulations currency exchange rates are assumed not to change so these are the same as national currency changes.

Source: Authors' GLOBAL-BEV model results. 
Table 2: Changes in volume of domestic consumption of beverages, 2020 and 2021 (\%, relative to no-COVID baseline)

(a) 2020

$\begin{array}{lrrrrrrrrr} & \text { WEur } & \text { UK } & \text { US\&Can } & \text { LatAmer } & \text { SthAfr } & \text { Asia } & \text { AUS } & \text { NZL } & \text { WORLD } \\ \text { All wine } & \mathbf{- 1 0} & \mathbf{- 4} & \mathbf{- 9} & \mathbf{- 1 1} & \mathbf{- 4} & \mathbf{- 4} & \mathbf{- 4} & \mathbf{- 4} & \mathbf{- 7} \\ \text { NPWine } & -4 & -3 & -6 & -4 & -2 & -3 & -3 & -4 & \mathbf{- 4} \\ \text { CPWine } & -5 & -3 & -5 & -5 & -2 & -3 & -3 & -4 & \mathbf{- 4} \\ \text { SPWine } & -4 & -1 & -5 & -3 & 0 & -1 & -1 & -3 & \mathbf{- 2} \\ \text { Sparkling } & -29 & -26 & -30 & -29 & -25 & -26 & -26 & -27 & \mathbf{- 2 8} \\ \text { Beer } & -6 & -3 & -6 & -6 & -3 & -4 & -4 & -5 & -\mathbf{4} \\ \text { Spirits } & -7 & -4 & -6 & -6 & -5 & -3 & -3 & -5 & \mathbf{- 5}\end{array}$

(b) 2021

$\begin{array}{lrrrrrrrrr} & \text { WEur } & \text { UK } & \text { US\&Can } & \text { LatAmer } & \text { SthAfr } & \text { Asia } & \text { AUS } & \text { NZL } & \text { WORLD } \\ \text { All wine } & \mathbf{- 4} & \mathbf{- 3} & \mathbf{- 5} & \mathbf{- 5} & \mathbf{- 2} & \mathbf{- 3} & \mathbf{- 3} & \mathbf{- 4} & \mathbf{- 4} \\ \text { NPWine } & -2 & -2 & -4 & -3 & -1 & -2 & -2 & -2 & \mathbf{- 2} \\ \text { CPWine } & -3 & -3 & -4 & -4 & -1 & -3 & -3 & -3 & \mathbf{- 3} \\ \text { SPWine } & -3 & -3 & -5 & -5 & -2 & -3 & -3 & -4 & -3 \\ \text { Sparkling } & -9 & -7 & -10 & -9 & -6 & -8 & -8 & -8 & -8 \\ \text { Beer } & -3 & -2 & -4 & -4 & -2 & -3 & -3 & -3 & -3 \\ \text { Spirits } & -4 & -3 & -4 & -4 & -4 & -3 & -3 & -3 & -4\end{array}$

Source: Authors' GLOBAL-BEV model results. 
Table 3: Changes in real value ${ }^{a}$ of domestic consumption of beverages, 2020 and 2021 (\%, relative to no-COVID baseline)

(a) 2020

$\begin{array}{lrrrrrrrr} & \text { WEur } & \text { US\&Can } & \text { LatAm } & \text { SthAfr } & \text { Asia } & \text { AUS } & \text { NZL } & \text { World } \\ \text { All wine } & \mathbf{- 1 6} & \mathbf{- 9} & \mathbf{- 1 4} & \mathbf{- 1 8} & \mathbf{- 1 0} & \mathbf{- 9} & \mathbf{- 8} & \mathbf{- 1 3} \\ \text { NPWine } & -8 & -5 & -7 & -7 & -5 & -5 & -6 & \mathbf{- 7} \\ \text { CPWine } & -11 & -8 & -10 & -10 & -7 & -8 & -10 & \mathbf{- 9} \\ \text { SPWine } & -7 & -4 & -8 & -7 & -4 & -3 & -5 & \mathbf{- 5} \\ \text { Sparkling } & -43 & -39 & -43 & -43 & -38 & -40 & -41 & \mathbf{- 4 1} \\ \text { Beer } & -10 & -7 & -10 & -10 & -6 & -7 & -8 & \mathbf{- 8} \\ \text { Spirits } & -9 & -7 & -9 & -9 & -9 & -7 & -9 & \mathbf{- 9}\end{array}$

(b) 2021

$\begin{array}{lrrrrrrrr} & \text { WEur } & \text { US\&Can } & \text { LatAm } & \text { SthAfr } & \text { Asia } & \text { AUS } & \text { NZL } & \text { World } \\ \text { All wine } & \mathbf{- 8} & \mathbf{- 8} & \mathbf{- 9} & \mathbf{- 9} & \mathbf{- 6} & \mathbf{- 8} & \mathbf{- 8} & \mathbf{- 8} \\ \text { NPWine } & -5 & -4 & -5 & -5 & -4 & -5 & -5 & \mathbf{- 5} \\ \text { CPWine } & -7 & -6 & -7 & -8 & -4 & -7 & -7 & \mathbf{- 6} \\ \text { SPWine } & -8 & -8 & -11 & -10 & -7 & -8 & -8 & \mathbf{- 8} \\ \text { Sparkling } & -13 & -12 & -15 & -15 & -11 & -13 & -13 & \mathbf{- 1 3} \\ \text { Beer } & -6 & -6 & -8 & -8 & -5 & -6 & -6 & \mathbf{- 6} \\ \text { Spirits } & -6 & -6 & -7 & -8 & -8 & -7 & -7 & \mathbf{- 7}\end{array}$

${ }^{a}$ Expressed in US dollars but in these simulations both exchange rates and overall national CPIs are assumed not to change so these are the same as nominal national currency changes.

Source: Authors' GLOBAL-BEV model results. 
Table 4: Changes in volume of wine exports, 2020 and 2021 (\%, relative to no-COVID baseline)

(a) 2020

$\begin{array}{lrrrrrrr} & \text { WEur } & \text { US\&Can } & \text { LatAmer } & \text { SthAfr } & \text { AUS } & \text { NZL } & \text { WORLD } \\ \text { All wine } & \mathbf{- 6} & \mathbf{- 3} & \mathbf{- 7} & \mathbf{- 3} & \mathbf{- 4} & \mathbf{- 2} & \mathbf{- 5} \\ \text { NPWine } & -1 & -2 & -6 & -3 & -4 & -3 & \mathbf{- 2} \\ \text { CPWine } & -1 & 0 & -8 & -2 & -3 & -2 & \mathbf{- 2} \\ \text { SPWine } & 0 & -3 & -6 & -1 & -4 & -2 & \mathbf{- 1} \\ \text { Sparkling } & -28 & -22 & -37 & -34 & -26 & -20 & \mathbf{- 2 8}\end{array}$

(b) 2021

$\begin{array}{lrrrrrrr} & \text { WEur } & \text { US\&Can } & \text { LatAmer } & \text { SthAfr } & \text { AUS } & \text { NZL } & \text { WORLD } \\ \text { All wine } & \mathbf{- 3} & \mathbf{1} & \mathbf{- 6} & \mathbf{- 1} & \mathbf{- 1} & \mathbf{- 2} & \mathbf{- 3} \\ \text { NPWine } & -1 & 0 & -4 & -2 & -2 & -1 & \mathbf{- 2} \\ \text { CPWine } & -1 & 2 & -5 & 0 & -1 & -1 & \mathbf{- 1} \\ \text { SPWine } & -1 & 0 & -9 & -2 & -1 & -2 & \mathbf{- 2} \\ \text { Sparkling } & -9 & -1 & -9 & 0 & -3 & -2 & \mathbf{- 9}\end{array}$

Source: Authors' GLOBAL-BEV model results. 
Table 5: Changes in real ${ }^{\mathrm{a}}$ value of wine exports, 2019 to 2021 (\%, relative to noCOVID baseline)

(a) 2020

$\begin{array}{lrrrrrrr} & \text { WEur } & \text { US\&Can } & \text { LatAmer } & \text { SthAfr } & \text { AUS } & \text { NZL } & \text { WORLD } \\ \text { All wine } & \mathbf{- 1 6} & \mathbf{- 9} & \mathbf{- 1 3} & \mathbf{- 1 1} & \mathbf{- 1 1} & \mathbf{- 7} & \mathbf{- 1 5} \\ \text { NPWine } & -6 & -7 & -10 & -9 & -9 & -7 & \mathbf{- 7} \\ \text { CPWine } & -10 & -9 & -14 & -11 & -10 & -12 & \mathbf{- 1 1} \\ \text { SPWine } & -5 & -9 & -10 & -6 & -8 & -6 & \mathbf{- 6} \\ \text { Sparkling } & -47 & -43 & -49 & -52 & -46 & -41 & \mathbf{- 4 7}\end{array}$

(b) 2021

$\begin{array}{lrrrrrrr} & \text { WEUr } & \text { US\&Can } & \text { LatAmer } & \text { SthAfr } & \text { AUS } & \text { NZL } & \text { WORLD } \\ \text { All wine } & \mathbf{- 1 0} & \mathbf{- 7} & \mathbf{- 1 1} & \mathbf{- 7} & \mathbf{- 7} & \mathbf{- 9} & \mathbf{- 9} \\ \text { NPWine } & -5 & -5 & -7 & -7 & -6 & -5 & \mathbf{- 6} \\ \text { CPWine } & -7 & -5 & -10 & -7 & -7 & -8 & \mathbf{- 8} \\ \text { SPWine } & -9 & -9 & -15 & -10 & -9 & -9 & \mathbf{- 9} \\ \text { Sparkling } & -15 & -10 & -14 & -11 & -11 & -10 & \mathbf{- 1 5}\end{array}$

${ }^{a}$ Expressed in US dollars but in these simulations both exchange rates and overall national CPIs are assumed not to change so these are the same as nominal national currency changes.

Source: Authors' GLOBAL-BEV model results. 
Table 6: Changes in volume and real ${ }^{\mathrm{a}}$ value of wine imports, 2019 to 2021 (\%, relative to noCOVID baseline)

Volume

Real $^{\mathrm{a}}$ value

(a) 2020

$\begin{array}{lrrrrlrrrr} & \text { WE } & \text { US\&Ca } & \text { Asia } & \text { World } & & \text { WE } & \text { US\&Ca } & \text { Asia } & \text { World } \\ \text { All wine } & \mathbf{- 7} & \mathbf{- 3} & \mathbf{- 2} & \mathbf{- 5} & \text { All wine } & \mathbf{- 1 7} & \mathbf{- 1 2} & \mathbf{- 1 1} & \mathbf{- 1 5} \\ \text { NPWine } & -3 & -1 & -1 & \mathbf{- 2} & \text { NPWine } & -8 & -6 & -7 & -7 \\ \text { CPWine } & -4 & -1 & 1 & \mathbf{- 2} & \text { CPWine } & -13 & -9 & -8 & \mathbf{- 1 1} \\ \text { SPWine } & -2 & 0 & 0 & \mathbf{- 1} & \text { SPWine } & -7 & -5 & -5 & \mathbf{- 6} \\ \text { Sparkling } & -27 & -24 & -22 & \mathbf{- 2 8} & \text { Sparkling } & -48 & -44 & -45 & \mathbf{- 4 7}\end{array}$

(b) 2021

$\begin{array}{lrrrrlrrrr} & \text { WE } & \text { US\&Ca } & \text { Asia } & \text { World } & & \text { WE } & \text { US\&Ca } & \text { Asia } & \text { World } \\ \text { All wine } & \mathbf{- 3} & \mathbf{- 2} & \mathbf{- 1} & \mathbf{- 3} & \text { All wine } & \mathbf{- 9} & \mathbf{- 9} & \mathbf{- 8} & \mathbf{- 9} \\ \text { NPWine } & -2 & -1 & 0 & \mathbf{- 2} & \text { NPWine } & -6 & -5 & -5 & \mathbf{- 6} \\ \text { CPWine } & -2 & -1 & 1 & \mathbf{- 1} & \text { CPWine } & -8 & -7 & -5 & \mathbf{- 8} \\ \text { SPWine } & -1 & -1 & -1 & \mathbf{- 2} & \text { SPWine } & -9 & -9 & -9 & \mathbf{- 9} \\ \text { Sparkling } & -7 & -8 & -6 & \mathbf{- 9} & \text { Sparkling } & -15 & -15 & -14 & \mathbf{- 1 5}\end{array}$

${ }^{\text {a }}$ Expressed in US dollars but in these simulations both exchange rates and overall national CPIs are assumed not to change so these are the same as nominal national currency changes.

Source: Authors' GLOBAL-BEV model results. 
Appendix Table 1: Aggregate consumption expenditure relative to the no-COVID businessas-usual baseline, 2020 and 2021(\%)

$\begin{array}{lrrlrr} & 2020 & 2021 & & 2020 & 2021 \\ \text { France } & -10.8 & -6.5 & \text { New Zealand } & -7.9 & -5.7 \\ \text { Italy } & -11.2 & -7.0 & \text { Canada } & -8.7 & -5.6 \\ \text { Portugal } & -11.3 & -6.9 & \text { United States } & -6.1 & -5.0 \\ \text { Spain } & -14.0 & -9.0 & \text { Argentina } & -12.2 & -8.4 \\ \text { Austria } & -7.9 & -4.7 & \text { Brazil } & -6.8 & -5.1 \\ \text { Belgium } & -9.4 & -5.8 & \text { Chile } & -7.6 & -5.1 \\ \text { Denmark } & -5.8 & -3.9 & \text { Mexico } & -9.9 & -7.8 \\ \text { Finland } & -5.3 & -3.2 & \text { Uruguay } & -6.2 & -3.8 \\ \text { Germany } & -6.8 & -3.8 & \text { Other L. Am } & -10.8 & -8.9 \\ \text { Greece } & -10.7 & -8.3 & \text { South Africa } & -8.9 & -7.0 \\ \text { Ireland } & -5.7 & -3.8 & \text { Turkey } & -7.9 & -6.3 \\ \text { Netherlands } & -6.6 & -4.1 & \text { North Africa } & -7.3 & -6.8 \\ \text { Sweden } & -6.2 & -4.4 & \text { Other Africa } & -5.8 & -6.5 \\ \text { Switzerland } & -6.4 & -4.1 & \text { Middle East } & -8.2 & -7.3 \\ \text { UK } & -10.7 & -6.3 & \text { China } & -4.5 & -2.8 \\ \text { Other W.E. } & -5.8 & -3.8 & \text { Hong Kong } & -8.7 & -6.7 \\ \text { Bulgaria } & -6.4 & -5.0 & \text { India } & -15.6 & -13.3 \\ \text { Croatia } & -10.6 & -7.0 & \text { Japan } & -6.0 & -4.5 \\ \text { Georgia } & -8.8 & -7.9 & \text { Korea } & -4.2 & -3.7 \\ \text { Hungary } & -8.1 & -6.6 & \text { Malaysia } & -9.9 & -6.8 \\ \text { Moldova } & -7.3 & -6.2 & \text { Philippines } & -12.2 & -9.5 \\ \text { Romania } & -7.3 & -5.6 & \text { Singapore } & -7.5 & -4.4 \\ \text { Russia } & -5.7 & -4.6 & \text { Taiwan } & -1.9 & -0.8 \\ \text { Ukraine } & -9.0 & -8.0 & \text { Thailand } & -9.8 & -8.7 \\ \text { Other E.E. } & -6.3 & -4.9 & \text { Other Asia } & -6.7 \\ \text { Australia } & -6.2 & -5.5 & \text { WORLD } & -5.5\end{array}$

Source: Authors' compilation based on GDP projections by IMF (2020) 